\title{
Ukraine's loss of human capital due to demographic, socio-economic and socio-political crises, 1990-2019
}

\author{
Oksana Zakharova* \\ Cherkasy State Technological University - Ukraine
}

Received: 19 May 2020 / Accepted: 1 October 2020

\begin{abstract}
The prosperity of the country's economy is possible only with the continuous accumulation of human capital. The article analyzes the factors influencing the accumulation of human capital in Ukraine during its independence. The article describes initial conditions that characterized the demographic and socio-economic development of Ukraine at the time of her independence. There were determined the criteria of influence on a person's decision-making on creating a family and getting a job, which in the long run determine the trends in the accumulation of human capital in the country. The most threatening trends of the influence of the demographic, socio-economic, and sociopolitical crisis on the processes of human capital accumulation in Ukraine are revealed. The article analyzes changes in Ukraine's rating among the world's countries by demographic and socio-economic indicators during 1990-2019.

Keywords

Labor migration / Human capital / Ukraine / Demographic crisis / Socio-economic crisis.

\section{Perdas de capital humano en Ucraína debido a crises demográficas, socioeconómicas e sociopolíticas, 1990-2019}

\section{Resumo}

A prosperidade da economía do país só é posible coa acumulación continua de capital humano. 0 artigo analiza os factores que influíron na acumulación de capital humano en Ucraína durante a súa independencia. Descríbense as condicións iniciais que caracterizaron o desenvolvemento demográfico e socioeconómico de Ucraína no momento da súa independencia. Determínanse os criterios de influencia na toma de decisións dunha persoa para crear unha familia e conseguir un emprego, que no longo prazo marcan as tendencias na acumulación de capital humano no país. Revélanse as tendencias máis ameazantes da influencia da crise demográfica, socioeconómica e sociopolítica nos procesos de acumulación de capital humano en Ucraína. Finalmente, analízanse os cambios na clasificación de Ucraína entre os países do mundo por indicadores demográficos e socioeconómicos durante o período 1990-2019.
\end{abstract}

Palabras clave

Migración laboral / Capital humano / Ucraína / Crise demográfica / Crise socioeconómica.

Códigos JEL: F22, J11, 015, R23.

\section{Introduction}

The desire for a better standard and quality of life is natural for a person and does not depend on time, country, gender, age, nationality, or religion. The basis of this desire is the struggle of the individual for the opportunity to provide himself and his family with access to the desired material wealth and a better future, the ability to survive in a rather aggressive external environment i.e. this is a person's internal need, the implementation of which has been continuously influenced by a significant number

\footnotetext{
*Corresponding author: bonheur5576@gmail.com
} 
of negative external factors - from unemployment and poverty and to natural disasters, epidemics, and active military operations directly in the region of their residence. Also, the modern world is quite tough for any deviations from the norm. If you are over 40 years old, you must have a certain illness and do not have the necessary level of education, knowledge, and financial capabilities, then getting the desired job and a decent wages is quite difficult, and in some circumstances, it is almost impossible. The way out of the situation is an active search for a better fate in another region of the country or abroad. Thus, the need for security and a decent standard of living in modern conditions of economic development of the region, country, and the world becomes a source of constant labor and professional mobility, which creates the phenomenon of labor migration, which is no longer local but global.

It should be noted that labor migration is not exclusively a new phenomenon for mankind, as in various forms and demonstrations it could be observed throughout its history, but in modern times its volume has become global due to significant differences in the level of economic development. According to the World Bank, labor migration covers about 3.0\% of the world's population, which has created an additional 15.0\% of world GDP (World Bank, 2018). At the world level, ceteris paribus, labor migration is a stimulating factor, as it increases the income and well-being of the migrant's family, which in general can reduce negative social problems such as unemployment, lack of housing, illiteracy, crime, and hunger.

At the same time, language, financial and legislative barriers, as well as a person's lack of opportunities and willingness to work, constrain the flows of labor migrants within certain quantitative limits, thereby balancing the situation with migration on the world labor market.

On the other hand, labor migration has different effects on the socio-economic development of host regions and donor regions of migrant workers. Countries belonging to the first group, due to labor migration, mostly receive socio-economic benefits: attracting sufficient cheap labor, closing vacancies for non-prestigious and difficult jobs in the labor market, increasing GDP and income, reducing social tensions, etc. The countries of the second group experience such negative consequences for economic development as reduction of the economically active population; the falling level of innovation of production technologies, extreme reduction of specialists in vital spheres of life, and deterioration of management decisions' quality at all levels due to migration of qualified youth, specialists with significant experience and scientists; non-return on investment in human capital and its gradual loss for the country. Ukraine ended up in this group of countries, whose economy has been in a deep crisis for a long time due to a large number of problems. Accordingly, the working-age population sees one way out of the crisis - employment abroad, which is only one reason for limiting the potential growth rate of its human capital.

\section{Starting conditions and potential for accumulation of human capital in Ukraine}

In December 1991, Ukraine, as one of the republics of the former USSR, held an all-Ukrainian referendum to establish the level of public support for the country's declaration of independence; as a result, it became an independent state.

From this moment all the economic relations that had developed by that time and had been worked out for many years were completely broken and had begun the difficult process of gradual restructuring of the Ukrainian economy on market principles, the creation and implementation of new mechanisms for managing all sectors of the economy and the introduction of changed fundamentals of their functioning, as well as establishing fundamentally new approaches to the activities of educational institutions, science, and medicine.

Additionally, during all twenty-eight years of the country's independence, the role of its human capital in the development of the economy transformed and the ways and mechanisms of its preservation and accumulation were determined. It is an attempt to answer the question "How successful were the reforms for the preservation and development of human capital in Ukraine throughout its independence?" and this work is devoted to answer this question. 
At the time of the proclamation of the independence, Ukraine is characterized by the following data, which, from different angles, determined its human potential and can be considered the starting conditions for its socio-economic development (State Statistics Service of Ukraine, 2020):

1) The population as of January 1, 1992: 52056.6 thousand people, $67.8 \%$ of which urban.

2) In the structure of the existing population $22.6 \%$ were children under the age of 16 and $12.6 \%$, persons aged 65 and over.

3) The number of live births per year was 630.8 thousand people; deaths, 669.9 thousand people, $52.1 \%$ of which for diseases of the circulatory system.

4) The number of live births per year per 1,000 population was $12.1 \%$; deaths, $12.9 \%$.

5) Natural population decline for the year amounted to 39.1 thousand people; migration growth, 151.3 thousand people.

6) The number of registered marriages per year: 493.1 thousand units; divorces, 200.8 thousand units.

7) Total annual birth rate: 1,776 children per woman during her lifetime, despite the fact that the highest birth rate was characteristic of the mother's age in the range of 20-24 years.

8) Average life expectancy at birth: 69.56 years, including for men, 64.62 years; for women, 74.21 years.

Ukraine's place in the world market in terms of socio-economic and demographic indicators for 1990 characterized as follows (World Data Atlas, 2020):

1) In terms of population: 22nd place among 197 countries.

2) According to the total birth rate: 161st place among 189 countries in the world.

3 ) In terms of the overall mortality rate: 41st place among 189 countries.

4) According to the total load coefficient: 169 place among 189 countries of in world.

5) According to the available GDP per capita at constant prices in 2010: 74 average 167 countries.

6) In terms of GDP at constant prices in 2010: 30th place among 167 countries.

7) According to the level of current expenditures on education, expressed as a percentage of GDP: 109th place among 189 countries.

Thus, the conditions that characterized Ukraine at the time of its independence were quite optimistic and gave hope for a significant improvement in the level and quality of life of the population in the future. At the same time, this hope was not unfounded, as it was supported by favorable natural and climatic conditions of Ukraine's location; the fact that $40 \%$ of Ukrainian lands were high-quality chernozem; the country's ownership of deposits of a significant range of minerals; sufficient level of development of industry, agriculture, cultural sphere. However, the main strategic resource of the country was human capital, namely highly professional specialists, which provided a very effective education system created in previous times. This thesis was confirmed by the 45th place occupied by Ukraine in 1990 according to the Human Development Index among 143 countries (United Nations Development Programme [UNDP], 2014; World Data Atlas, 2020).

\section{Criteria for influencing human decision-making, which, in the long run, determine the trends of human capital accumulation in the country}

Each person chooses his own way of life depending on the personal and external circumstances that prevailed at the time of choice and stereotypes about the levers of ensuring the desired quality of life, formed in public opinion. There are a large number of criteria for such a choice, as each person due to the psycho-emotional characteristics of the individual at any time prefers one or another component of "quality of life" or feels the need for specific symbols of a satisfactory standard of living (Czapliński \& 
Dzhaman, 2019; Dluhopolskyi, Zatonatska, Lvova \& Klapkiv, 2019; Kolot \& Herasymenko, 2017; Markina, Sharkova \& Barna, 2018). In generalized form, we can distinguish twelve criteria, depending on the degree of satisfaction of each at a particular time, a person makes a conclusion about the level and quality of their own lives, and therefore decides on the steps to be taken in the near future to improve the formed situation. Such criteria include: marital status; availability of decent work and working conditions; provision of real estate; availability of movable property; a level of education and prestige of the diploma; health status of the person and family members; opportunities for quality annual recreation; opportunities to provide a decent level of education and health care for themselves and family members; professional ambition; opportunities to meet consumer needs; cash savings. This list can be extended, but these factors determine the basic contour of the range of human decisionmaking which are important for building the trajectory of his life, which underlie the formation of trends in the accumulation of personal and social human capital (Zakharova, 2019).

The same circumstances of life are considered by each person differently, from an optimistic or pessimistic point of view, depending on the degree of satisfaction with the existing standard of living, age, health status, place of residence and the availability of real opportunities to radically change something in their own life in the near future. At the same time, one person can consider the lack of a certain good as an insurmountable problem and a reason for losing hope for a better life, and another as an incentive for specific actions, professional and personal development, and the search for options for achieving what they want. The angle of view chosen by a person determines not only his psychoemotional state and the choice of ways to achieve his goals, but also forms the social position of the individual, his vision of his own future and the future of his country.

At the same time, if for one person, regarding his worldview and formed views on life, three or more unsatisfactory answers coincide for the selected criteria, and there is no possibility of receiving outside help of financial or other nature or at least hope for it, he is faced with the need to accept a difficult decision for himself about the expediency of introducing radical changes in his own life. Options for such changes may be: change in marital status; making a conscious decision about the desired number of children in the family and the age at which children can be born; moving from one area to another; change of place of work, profession, type of activity both with additional education and without it; labor migration.

The unequivocal answer whether the person made the right decision to receive the expected benefits arrives only after a certain, quite long period. At the same time, the general tendencies of the country's socio-economic development, the rate of accumulation of human capital at the individual, regional and national levels, and the possibilities of innovative development of the country's economy will depend on which path each person takes.

Since 1991, the population of Ukraine has found itself in a zone of constant turbulence and the need to permanently change their lives, choose popular or unpopular solutions, which were largely determined by external aggressive circumstances and ultimately affected the country's fate. Thus, during the first seven to nine years of independence, the closure or restriction of markets and the lack of supply of raw materials forced the closure of a huge number of large industrial enterprises with the dismissal of workers. At this time, the formation of the principles of the business environment of the country began in the absence of clear rules of entrepreneurial activity, permissiveness, and excessive riskiness of any economic operations (Petrova \& Mosiychuk, 2016; United Nations Development Programme in Ukraine, 2010). The beginning of the new millennium was marked for Ukraine by the gradual formation of the boundaries of the legal field and the rapid creation of economic entities against this background, which adapted to new economic conditions and in the absence of the necessary knowledge, had a high probability of loss. Four years before the global financial crisis in 2008 was considered the most stable and profitable for the business environment of Ukraine when the profitability of enterprises reached the maximum level for the entire period of the study, and household incomes began to grow. The next four years were associated with the desire of employers to cover the losses incurred during the crisis, the increase in the scale of entrepreneurship, and the intensification of labor migration. Since 2014, because of the annexation and occupation of part of the territory, Ukraine 
has lost a strong part of its industrial and human potential, and the process of forced displacement of the population has begun.

Thus, the twenty-nine years that have passed since Ukraine's independence is sufficient time to begin to conclude the correctness of certain decisions that have been made by each person during all this time.

\section{Characteristics of trends in the demographic crisis in Ukraine}

At the heart of achieving continuous trends in the accumulation of human capital in the country lay mostly three key prerequisites - the favorable demographic processes, the quality education system, balanced with the laws of the labor market and the efficient system of social production. At the same time, the favorable demographic situation in the country simultaneously depends on the presence of two opposite trends, which in fact may have different quantitative ratios - an increase in the birth rate and a reduction in the mortality rate. A large number of factors, the profile of which will differ significantly for each country, influences each of these trends.

The years of independence led to the conclusion that the restrictions that may hinder the growth of the birth rate for the Ukrainian family were: the lack of stability in the country's economy; inability to get a decent job; deterioration of the family's financial situation and lack of sources for its improvement in the near future; lack of own housing or unsatisfactory living conditions; inability to provide children with everything they need and provide them a quality education (Grishnova \& Kostenko, 2011; Kolot, 2010; Kupets, Vakhitov \& Babenko, 2013; Mishchuk \& Grishnova, 2015; Petrova \& Mosiychuk, 2016). All these restrictions accompanied the lives of Ukrainians throughout the study period, which, along with rising mortality, gradually plunged the country into a demographic crisis, which resulted in an intense process of population decline (Figure 1). The dynamics of mortality in the country is also natural to the socio-economic phenomena that were observed in the country and is associated with low material condition of the population, unsatisfactory quality of food, deteriorating ecological condition of the territory, deteriorating health of Ukrainians, unsatisfactory level of health care and lack of funds for it. It should be noted, that there are currently no reliable data on the real population of the country, as the first and last All-Ukrainian population census took place in December 2001 (All-Ukrainian Population Census, 2001).

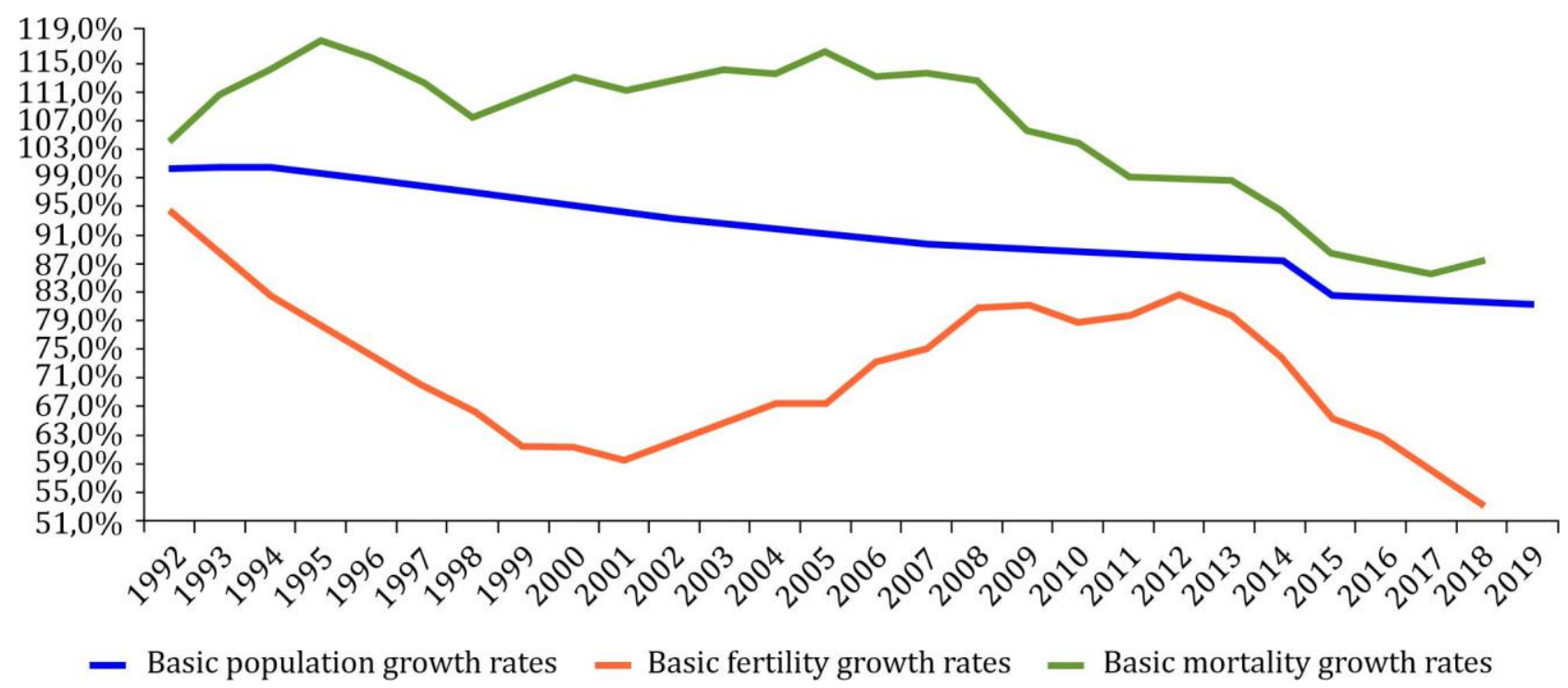

Figure 1. Trends in the Changing of Ukraine's Population during 1992-2019, its births and deaths compared to 1991. Source: State Statistics Service of Ukraine (2020). 
The entire period of the study on the homogeneity of the trends in the impact of fertility and mortality on the dynamics of the population of Ukraine can be divided into three time intervals:

-1991-2001: the number of births decreased by 25.4 thousand annually, which led to the largest value of this indicator in the interval of decline; in 2001 the number of births in the country decreased by $32.45 \%$ compared to 1991 and accounted for only $0.77 \%$ of the population; the number of deaths in the country increased by an average of 7.6 thousand annually, and the maximum mortality rate was reached in 1995 when $1.53 \%$ of the country's population died. As a result, the population decreased by 369.5 thousand people annually due to natural movement;

-2002-2012: during the period there were mostly positive trends in the growth of the number of births in some cases, its reduction, which was characterized by an average annual population growth of 13.1 thousand people; the number of deaths in the country decreased by an average of 7.5 thousand people annually. As a result, on average, the population decreased by 267.4 thousand people annually due to natural movement;

-2013-2019: the number of births decreased by 30.8 thousand people annually, which led to the largest decline in the value of this indicator for the entire period of the study; in 2018 the number of births in the country decreased by $46.75 \%$ compared to 1991 ; the number of deaths in the country decreased by an average of 12.6 thousand people annually, and the lowest mortality rate was reached in 2017 when $1.35 \%$ of the country's population died. As a result, on average, the population decreased by 192.8 thousand people annually due to natural movement.

These demographic trends have led to a reduction in the country's population from 51,944.4 thousand people in 1991 to 42,153.2 thousand people in 2019 or 18.8\% (State Statistics Service of Ukraine, 2020). This means there was a gradual annual decline in population with a sharp jump in 2014, due to the exclusion from statistical calculations of the annexed and temporarily occupied territories of the country.

There is no doubt that population decline has a negative impact on the country's human capital. However, in Ukraine this reduction was accompanied by a significant deterioration in the age structure of the population, which had a more negative impact on the trends of human capital accumulation (Figure 2).

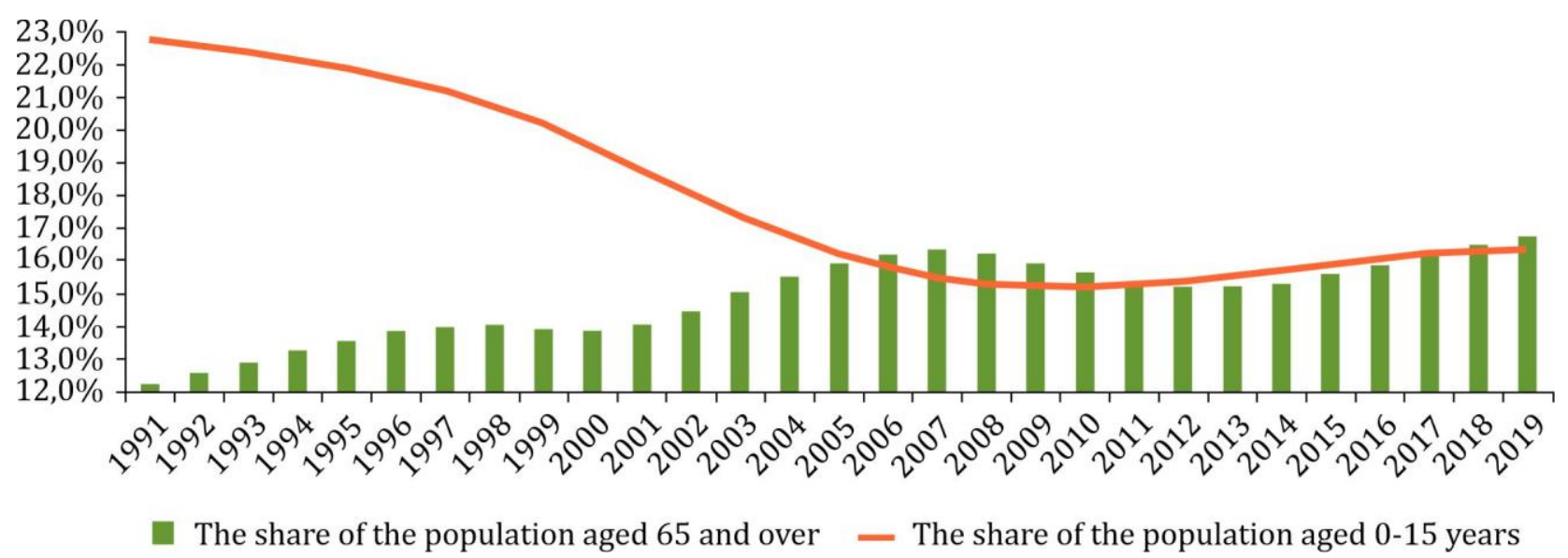

Figure 2. Trends of changes in the share of young and the elderly people in the total population of Ukraine for the period 1991-2019. Source: State Statistics Service of Ukraine (2020).

If in 1991 young people accounted for $22.78 \%$ of the population against $12.26 \%$ of the elderly population, in 2019 the situation changed - the share of young people decreased to $16.35 \%$ against 
$16.76 \%$ of people aged 65 and over (State Statistics Service of Ukraine, 2020). At the same time, it is necessary to pay attention to a rather interesting aspect - until 2011, the dynamics of the share of young and elderly people in the total population of the country had a mirror opposite trend, and later acquired a one-way movement in the direction of growth. Thus, over the last ten years, there have been positive changes in the structure of the population, although in absolute terms the situation continues to deteriorate. In 2019, the lowest number of children for the entire period of independence was born: 335.9 thousand people.

Thus, the reduction of the country's population, both due to falling birth rates and accelerating mortality rates, is one of the greatest threats to the stabilization and development of Ukraine's economy, leading to an aging population and loss of human capital, both existing and potential.

\section{Characteristics of trends in the socio-economic crisis in Ukraine}

Mastering the basics of a market economy and building its own system of adaptation to new living conditions have gradually turned Ukraine mostly into a supplier of raw materials to developed countries and a consumer of imported finished goods (Petrova \& Mosiychuk, 2016). Such changes have significantly distorted the labor market in the country, which has acquired mostly negative characteristics.

Firstly, historically, there has been a significant heterogeneity in the country's labor market, since in some regions there was a shortage, and in others - a surplus of labor (Bublyk, Udovychenko \& Medvid, 2019). The reasons for such deformations can be considered differences in economic development and the intensity of demographic processes in different regions of the country; the development of certain areas of economic activity and, as a consequence, the presence of more or less environmental problems that affect the quality and duration of human life. Due to such discrepancies, more than in 8-10 times the level of income, labor productivity, invested funds, and other economic indicators differ that are typical for the capital of Ukraine, Kyiv, and less developed regions of the country, such as Luhansk, Chernivtsi, Kirovohrad regions (Kharlamova, Chala, Gumenna \& Osinchuk, 2020). This creates internal labor mobility, which today involves up to $9 \%$ of the working population (International Organization for Migration. Mission in Ukraine, 2016a, 2016b). As a result, intensive economic development due to the inflow of labor and investment occurs only in large cities such as Kyiv, Dnipro, Lviv, Kharkiv, and Odesa.

In general, the labor market of Ukraine is characterized by a reduction in the number of jobs while increasing unemployment, Figure 3 (European Training Foundation, 2019). At the same time, the most critical periods for the labor market were the periods during 1996-1998, 2009 and 2013-2016, when due to the aggravation of socio-economic problems in the regions of the country there was a sharp increase in unemployment. It should be noted that a person's stay in a state of unemployment significantly strengthens the trend of a devaluation of knowledge, which triggers a negative process of reducing the amount of human capital.

Secondly, due to the lack of effective levers to balance the demand for specialists and the proposals for their training by educational institutions, an imbalance in the labor market arose based on professional characteristics (European Training Foundation, 2019; Kupets, 2012). This imbalance is based on the public opinion formed in the country about the prestige of certain professions, the expectations of school graduates, and their parents about the activities that will surely bring high income in their future.

As a result, there was a significant shortage of medical specialists, engineers, and teachers, with a significant excess of IT specialists, economists, and lawyers. Legislative regulation does not solve this problem radically - budget places in educational institutions for socially useful professions are not filled one hundred percent despite the fact that the demand for IT specialties, economic specialties, and lawyers is growing even for a paid education. In addition, the costs for Ukrainian higher education tend 
to gradually increase, only recently they have increased from $32.4 \%$ of GDP per capita in 2004 up to 41.4\% in 2012 (World Data Atlas, 2020). As a result, the problem of employment of higher education institutions graduates' arose, solved by obtaining jobs not in their specialty or unofficially. At the same time, there is a rather high level of youth unemployment, which during the period reached $25 \%$ (State Statistics Service of Ukraine, 2020), and becomes the most difficult form to overcome.

Due to the indicated trends in expenditures directed from state sources to finance education, in most cases it can be considered ineffective and even lost (Figure 4).

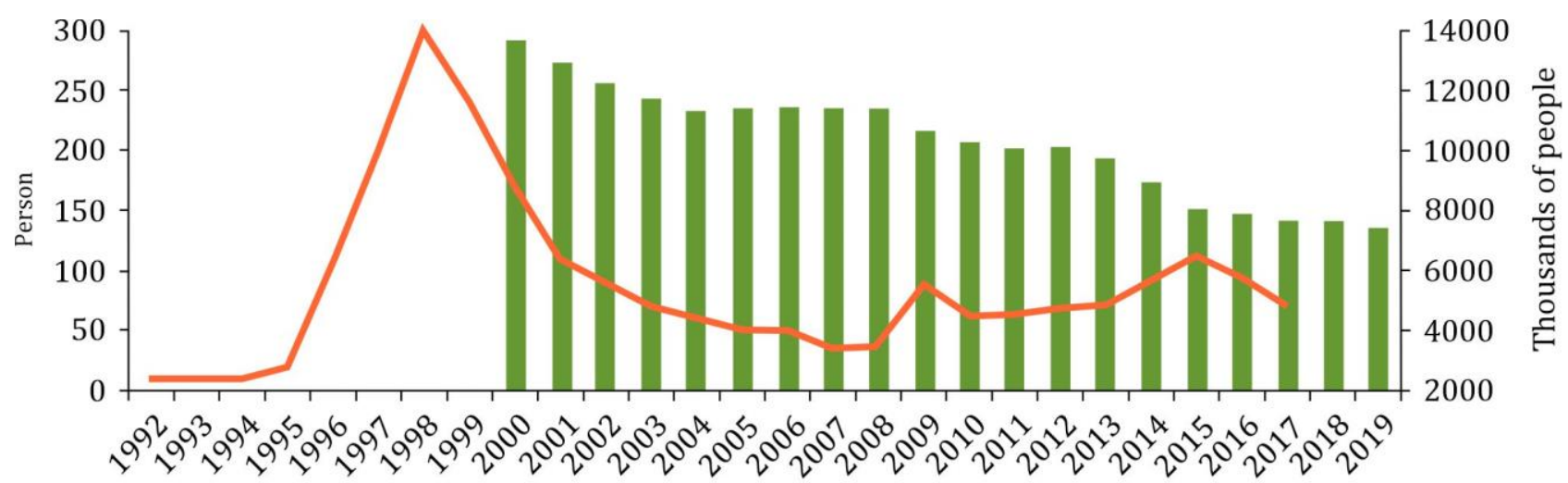

The average number of full-time employees, thousands of people

- The average number of registered unemployed persons for 10 vacancies, person

Figure 3. Dynamics of changes in the average number of full-time employees and the average annual workload of registered unemployed per 10 vacancies in Ukraine for the period 1992-2019. Source: State Statistics Service of Ukraine (2020).

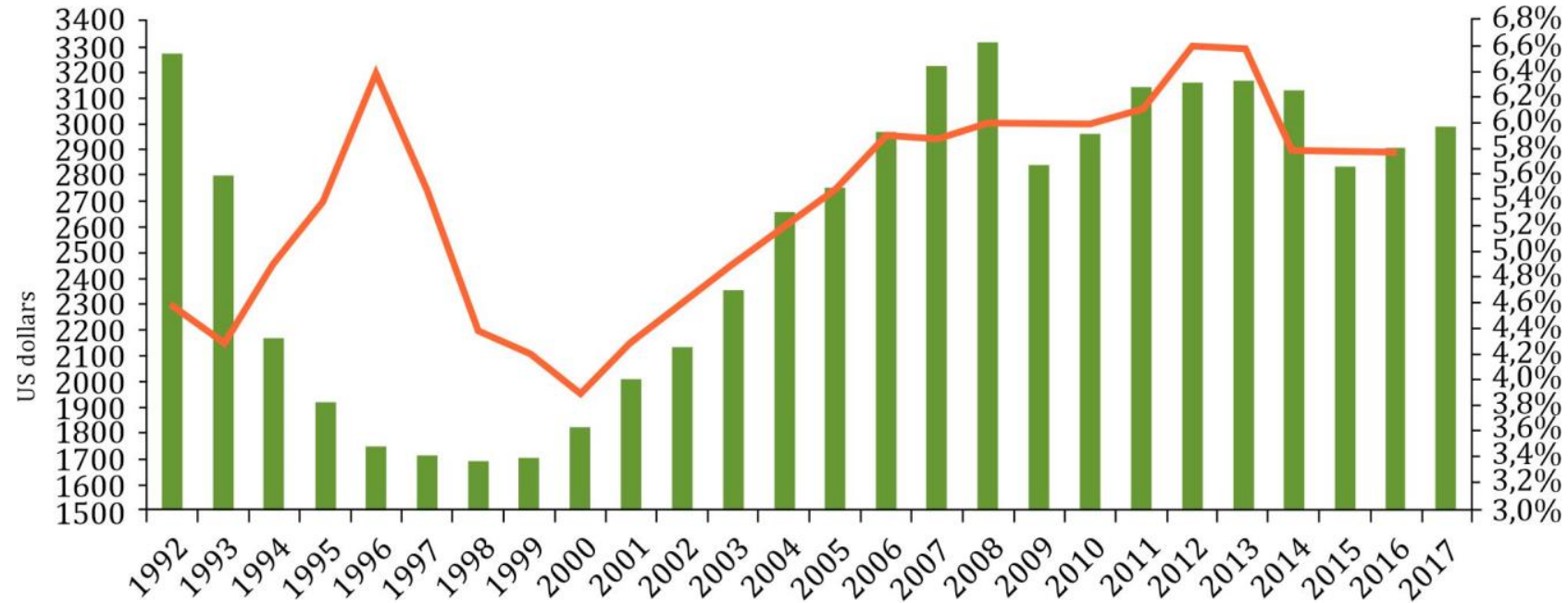

GDP per capita at constant prices in 2010, US dollars - Current expenditures on education, \% of GNI

Figure 4. Dynamics of change in GDP per capita and the percentage of expenditures on education from GNI in Ukraine for the period 1992-2017. Source: State Statistics Service of Ukraine (2020).

Basically, expenditures on education in the country do not pay back and do not contribute to the intensive accumulation of human capital, which can be confirmed by the lack of positive trends in 
production, profits, income and other economic indicators. This situation arose, due to the significant number of risks that affected the processes of professional development of workers in the country throughout its independence (Zakharova \& Kratt, 2014). It can be noted that the expenditures on education, the share of which, (not including 1993, 1998-2001), significantly exceeded the corresponding level of 1992, contributes to maintaining the general level of education of the country's population, which allows them to be quite mobile in the domestic and foreign labor market. Confirmation of these words is the current GDP per capita (except 2008), which was created in Ukraine in 1992. Despite the fact that the population is declining every year, the conclusions about the dynamics of the country's GDP are even more pessimistic. Thus, the tendency to reduce the amount of human capital in Ukraine is simultaneously accompanied by the impossibility of obtaining the expected return on investment in it.

Thirdly, according to experts in Ukraine, informal employment covers up to 23\% of the working population (International Organization for Migration. Mission in Ukraine, 2016a, 2016b; Kupets, Vakhitov \& Babenko, 2013). This form of employment is illegal, although it is clearly beneficial to both employees who receive a larger amount of money and employers. However, the spread of this form of employment has a devastating effect on the ability of the state social security system to perform its functions, resulting in low average wages, pensions and other social benefits do not provide the population with decent working and living conditions (International Labour Organization, 2011; Organisation for Economic Co-operation and Development [OECD], 2012). The acquired tendency leads to the devaluation of the role of social institutions of the State in society, strengthens the desire of persons exclusively to the maximum exploitation of their own knowledge, skills and abilities instead of introducing mechanisms of continuous personal and professional development. Thus, the lack of a strategic approach to the accumulation of human capital in the country leads to a reduction in trends of its activation and loss.

Fourth, low labor costs are one of the painful points of the Ukrainian labor market, which creates a rather acute problem for Ukraine to intensify labor migration (Borjas, 2005; Ptoukha Institute for Demography and Social Studies of the National Academy of Sciences of Ukraine, 2020; Scheve \& Slaughter, 2001). Indeed, the level of wages is the main factor in a person's final decision on the feasibility of employment and getting an education in order to obtain a certain profession. During the period 2002-2018, there was an annual positive dynamics of growth of the average monthly wage in the industry of Ukraine (Figure 5). Thus, in 2018 compared to 2002, the average monthly wage in Ukraine increased 19.9 times.

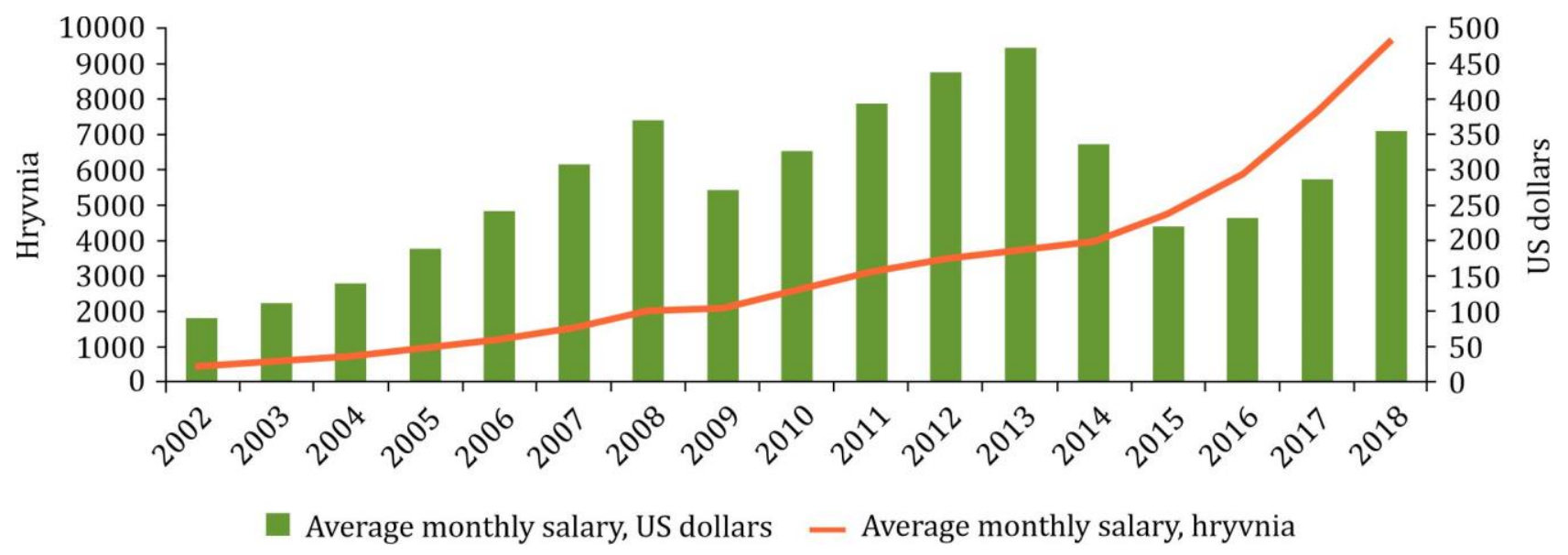

Figure 5. Dynamics of the average monthly wage in the industry of Ukraine in hryvnia and dollar equivalents during 2002-2018. Source: State Statistics Service of Ukraine (2020). 
However, analyzing the dynamics of the dollar equivalent of the average monthly wage, the picture looks much sadder and pessimistic. During the study period, the average salary increased only 3.9 times - from 91.1 USD in 2002 to 354.1 USD in 2018 per month. After each crisis year, the country has seen a sharp decline in the dollar equivalent of wages, which was typical for 2009 and 2014-2015. The last reduction was not fully removed in subsequent years, and as a result, the level of wages in Ukraine is much lower than in neighboring countries of the post-Soviet bloc (the Russian Federation: 699.1 USD, the Republic of Belarus: 476.1 USD), Kazakhstan: 471.9 USD) and developed European countries (Poland: 1350 USD, Czech Republic: 1418 USD, Germany: 4384 USD) (Eurostat, 2020). Under such conditions, to form an effective system of human capital accumulation in the country is quite difficult, as well as to retain their own qualified personnel.

Fifth. A comparison of the data on the average level of wages with the shortage of jobs in the labor market of Ukraine leads to a definite answer. An able-bodied person who does not have a decent job or a sufficient level of income and needs to improve his or her life will be forced to decide to work abroad, which, despite the difficulties and risks, will allow him to earn many times more. Such a solution is quite easy to implement due to the presence of a developed network of agencies, offices, and services that operate legally in Ukraine and, if licensed, provide a comprehensive set of intermediary services for the organization of foreign employment of Ukrainians. As a result, according to various estimates, 2.7-3.2 million Ukrainians work abroad permanently today (International Organization for Migration. Mission in Ukraine, 2016a, 2016b; Ptoukha Institute for Demography and Social Studies of the National Academy of Sciences of Ukraine, 2020).

Annual remittances of Ukrainian labor migrants, which reach a total amount of 11-12 billion USD are a significant factor in improving the purchasing power and living standards of their families in Ukraine (Ptoukha Institute for Demography and Social Studies of the National Academy of Sciences of Ukraine, 2020). It is this factor that motivates another $12 \%$ of the country's population that according to a survey of sociologists, will make efforts to get a job abroad in the near future (Research \& Branding Group, 2020). At the same time, today $3 \%$ of these people stated that they do not plan to return to Ukraine. Thus, labor migration leads both to a temporary reduction and directly to the country's loss of human capital.

Under such conditions, we should not expect an innovative breakthrough in the economic development of the country due to the accumulation of human capital in the near future.

\section{Characteristics of trends in the socio-political crisis in Ukraine}

Since 2014, in Ukraine, due to the acute phase of the socio-political conflict and the temporary loss of a certain part of the Ukrainian territories, there has begun a new social phenomenon that is associated with the forced relocation of the population from the temporarily occupied territories of Donetsk and Luhansk regions, the Autonomous Republic of Crimea (Ukrainian Centre for Economic and Political Studies Named after Olexander Razumkov, 2019). These regions played a very strong role in the socioeconomic, investment-innovative, production-technological and cultural development of the country, had significant deposits of natural resources and developed resort and recreational areas. Thus, the share of the employed population aged 15-70 in the three occupied regions in the total number of employed population of the specified age range in 2013 was $19.0 \%$; and the share of gross regional product, 17.4\% (State Statistics Service of Ukraine, 2020). In 2015, the share of the employed population aged 15-70 in the occupied regions in the total number of employed population in the specified age range of the country was only $6.5 \%$, and the share of gross regional product, $6.9 \%$ (State Statistics Service of Ukraine, 2020).

That is why the withdrawal of the Autonomous Republic of Crimea and parts of Donetsk and Luhansk regions from national economic relations led to a significant transformation of the labor market and a sharp decline in 2014 of all statistical indicators characterizing the vital activity of Ukraine and contributed to an even greater aggravation of the demographic and socio-economic crisis in the country. 
At the same time, part of the population of these regions for various reasons remained living in the occupied territories, as a result, it was completely excluded from the statistics on the total population of Ukraine during the occupation. The second part of the population of the occupied territories left Ukraine for permanent residence. These two categories of Ukrainians today are a $100 \%$ loss in terms of human capital in Ukraine.

A third of the population of the occupied territories moved to the controlled part of the territory of Ukraine. According to official data, as of the beginning of September 2016, 1,709,083 internally displaced persons, or $4 \%$ of the total population, were registered, and at the end of April 2020, their number decreased to 1,446,840 (Ministry of Social Policy of Ukraine, 2020). The tendency to reduce the number of registered internally displaced persons is associated with the natural movement of the population, their return to the occupied territory, and departure from the country.

The decision to return is mostly made due to difficulties in integrating internally displaced persons into host communities, lack of effective state support, lack of housing, unsatisfactory financial situation, difficulties in obtaining decent and professional work, conflicts with the local population. Given the fact that the majority of internally displaced persons are young people with higher education $(40 \%$ are people under the age of 35 and more than $70 \%$ have higher education), the loss of each of them has a significant negative impact on Ukraine's human capital (Ministry of Social Policy of Ukraine, 2020; Refugees and Internally Displaced Persons, 2015; Ukrainian Centre for Economic and Political Studies Named after Olexander Razumkov, 2019). That is why, to preserve the human capital of the occupied territories of Ukraine at the regional and state levels, effective programs should be created to fully support the processes of integration of internally displaced persons into a peaceful and stable life.

\section{Comparisons}

The total effect of each of the aspects highlighted in the article, which directly influenced the trends of human capital accumulation in Ukraine during its independence, led to a significant deterioration of the country's place in the world rankings, Table.1.

Table 1. Rating of Ukraine in the world by demographic and socio-economic indicators during 1990-2019, the place of Ukraine / number of countries that participated in the study

\begin{tabular}{|c|c|c|c|c|c|c|c|c|c|c|}
\hline Indicator & 1990 & 2000 & 2005 & 2010 & 2014 & 2015 & 2016 & 2017 & 2018 & 2019 \\
\hline $\begin{array}{l}\text { Population (place among } 196 \\
\text { countries) }\end{array}$ & 22 & 23 & 27 & 28 & 31 & 31 & 31 & 31 & 31 & 32 \\
\hline $\begin{array}{l}\text { Total birth rate (place among } \\
189 \text { countries) }\end{array}$ & 161 & 186 & 184 & 170 & 166 & 167 & 167 & 168 & 169 & 169 \\
\hline $\begin{array}{l}\text { Overall mortality rate (among } \\
189 \text { countries) }\end{array}$ & 41 & 16 & 8 & 4 & 2 & 2 & 3 & 2 & 2 & 2 \\
\hline GDP at constant prices in 2010 & $\begin{array}{l}30 / \\
167\end{array}$ & $\begin{array}{l}54 / \\
188\end{array}$ & $\begin{array}{l}52 / \\
190\end{array}$ & $\begin{array}{l}54 / \\
194\end{array}$ & $\begin{array}{l}59 / \\
191\end{array}$ & $\begin{array}{l}59 / \\
191\end{array}$ & $\begin{array}{l}59 / \\
191\end{array}$ & $\begin{array}{l}59 / \\
190\end{array}$ & $\begin{array}{l}58 / \\
188\end{array}$ & - \\
\hline $\begin{array}{l}\text { GDP per capita at constant prices } \\
\text { in } 2010\end{array}$ & $\begin{array}{c}169 / \\
189\end{array}$ & $\begin{array}{c}126 / \\
188\end{array}$ & $\begin{array}{c}117 / \\
190\end{array}$ & $\begin{array}{c}125 / \\
194\end{array}$ & $\begin{array}{c}125 / \\
191\end{array}$ & $\begin{array}{c}129 / \\
191\end{array}$ & $\begin{array}{c}128 / \\
191\end{array}$ & $\begin{array}{c}127 / \\
190\end{array}$ & $\begin{array}{c}125 / \\
188\end{array}$ & - \\
\hline $\begin{array}{l}\text { The level of current expenditures } \\
\text { on education, } \% \text { of GDP (place } \\
\text { among } 189 \text { countries) }\end{array}$ & 109 & 90 & 34 & 33 & 36 & 46 & 69 & 68 & - & - \\
\hline Human Development Index & $\begin{array}{l}45 / \\
143\end{array}$ & $\begin{array}{l}78 / \\
173\end{array}$ & $\begin{array}{l}74 / \\
185\end{array}$ & $\begin{array}{l}82 / \\
187\end{array}$ & $\begin{array}{l}85 / \\
187\end{array}$ & $\begin{array}{l}88 / \\
187\end{array}$ & $\begin{array}{l}88 / \\
187\end{array}$ & $\begin{array}{l}87 / \\
188\end{array}$ & $\begin{array}{l}87 / \\
188\end{array}$ & - \\
\hline
\end{tabular}

Source: World Data Atlas (2020). 
During the period of independence, the situation with the significant deterioration of the demographic situation in the country was the most painful. Due to the annual strengthening of negative trends in the demographic sphere, today Ukraine has become the second country in the world in mortality rate and only 169 th in birth rate. Such negative dynamics is the basis for the rapid population decline, as a result Ukraine has moved from 22 nd to 32 nd place in the world. The continuation in time of acquired trends can become a threat not only to the accumulation of human capital of the country but also to the preservation of the Ukrainian national identity.

At the same time, the socio-economic situation in the country deteriorated, which was illustrated by the fall in GDP, due to which Ukraine moved from 30th to 58th place in the global ranking. The growth of GDP per capita cannot be considered a positive factor, as it is not associated with an increase in GDP, but with the annual decline in population in the country. Thus, the productive return on human capital accumulated in the country has a negative trend, which is evidence of its gradual depreciation.

During the entire study period, there was a tendency to increase the level of current spending on education in Ukraine. This dynamic is a very positive trend for the strategic development of the country, but with intensive labor immigration of Ukrainians, it can be characterized as a direct loss of part of these costs for the country at the time of the absence of Ukrainians on its territory. Especially threatening is the trend of labor migration of graduates of all educational institutions, representatives of professions that are in short supply for the country's economy, and experienced specialists from the occupied territories of Ukraine.

The combined effect of these trends led to the fact that the Human Development Index in Ukraine in 2018 fell almost twice compared to the initial conditions - from 45th to 87th place. The acquired trend is very threatening for the socio-economic development of Ukraine and therefore requires professional development and implementation of effective management decisions of a strategic nature.

\section{Conclusions}

A thorough assessment of the factors influencing a person's final decision on marriage, childbirth or employment outside the country, in the current conditions of development of the Ukrainian economy has led to disappointing conclusions. If the regional and state authorities do not make effective decisions in the near future, it is highly probable that the consequences of the demographic and socio-economic crisis in the country will intensify in the future. As a result, there will be an increase in the flow of Ukrainian migrant workers to other countries. Such a negative scenario will further intensify the manifestation of negative trends in socio-economic, financial, demographic and other areas, further plunging the country into crisis. That is why the declared factors should become the goals that should be the basis for the formation of a strategy for the development of the regions of Ukraine for the next five to seven years. Only under such conditions, could there be expected an increase in the birth rate and the return of Ukrainian workers to their homeland.

The problems considered in the article can be solved only if the course of state and regional policy is shifted from the political to the socio-economic sphere, the main goal for the country's authorities will be to achieve a high quality of human life, providing it with all the services necessary for a full life, resources and opportunities. Such decisions should be the creating of conditions for intensive development of small and medium-sized businesses, improving the quality of educational services and their clear focus on the needs of regional labor markets, comprehensive social protection of all segments of the population, and paying more attention to decent living and working conditions for displaced persons from temporarily occupied territories.

Only under such conditions is it possible not only to slow down and stop the flow of Ukrainian labor migrants outside the country but also to gradually create opportunities for their final return to Ukraine. The consolidation of these trends over time will give the Ukrainian economy a powerful impetus for stabilization and development. Also, the knowledge and experience gained by Ukrainian workers 
outside the country should become an additional lever of innovative development and progress, which should be passed on to the younger generation of Ukrainians.

\section{References}

All-Ukrainian Population Census. (2001). Retrieved from: http://2001.ukrcensus.gov.ua/

Borjas, G. J. (2005). The labor market impact of high-skill immigration. American Economic Review, 95(2), 56-60. DOI: https://doi.org/10.1257/000282805774670040

Bublyk, M., Udovychenko, T., \& Medvid, R. (2019). Concept of smart specialization in the context of the development of Ukraine's economy. Economics. Ecology. Socium, 3, 55-61. DOI: https://doi.org/10.31520/2616-7107/2019.3.2-6

Czapliński, P., \& Dzhaman, V. (2019). Problems of the Ukrainian labor market. Journal of Geography, Politics and Society, 9(4), 24-34. DOI: https://doi.org/10.26881/jpgs.2019.4.03

Dluhopolskyi, O., Zatonatska, T., Lvova, I., \& Klapkiv, Y. (2019). Regulations for returning labour migrants to Ukraine: international background and national limitations. Comparative Economic Research, 22(3), 45-64. DOI: http://doi.org/10.2478/cer-2019-0022

European Training Foundation. (2019). Youth transition to work in Ukraine. Turin, Italy: European Training Foundation. Retrieved from: https://www.etf.europa.eu/sites/default/files/2019-07/Youth\%20transition\%20Ukraine.pdf

Eurostat. (2020). Labour market, including labour force survey (LFS) - Overview. Luxembourg, Luxembourg: Eurostat. Retrieved from: https://ec.europa.eu/eurostat/web/labour-market/overview

Grishnova, O., \& Kostenko, T. (2011). New approaches to motivating labor taking into account the system of life values of youth. Ukraine: Aspects of Labor, 7, 3-8.

International Labour Organization. (2011). Decent work country profile: Ukraine. Geneva, Switzerland: International Labour Organization-ILO. Retrieved from: http://www.oit.org/wcmsp5/groups/public/--dgreports/---integration/documents/publication/wcms_167363.pdf

International Organization for Migration. Mission in Ukraine. (2016a). Migration in Ukraine: Facts and figures. Kyiv, Ukraine: IOM Ukraine. Retrieved from: www.iom.org.ua/sites/default/files/ff eng 1010 press.pdf

International Organization for Migration. Mission in Ukraine. (2016b). Migration as an enabler of development in Ukraine. Kyiv, Ukraine: IOM Ukraine. Retrieved from:

http://www.iom.org.ua/sites/default/files/iom migration as an enabler of development in ukraine.pdf

Kharlamova, G., Chala, N., Gumenna, O., \& Osinchuk, T. (2020). The regional resources of ukraine and new opportunities for economic development until 2030. The Market for Ideas, 25. Retrieved from: http://www.themarketforideas.com/the-regional-resources-of-ukraine-and-new-opportunities-foreconomic-development-until-2030-a427/

Kolot, A., \& Herasymenko, O. (2017). A deficit of decent work as a current trend in the development of social and labor sphere in Ukraine. Knowledge and Performance Management, 1(1), 5-18. DOI: http://dx.doi.org/10.21511/kpm.01(1).2017.01

Kolot, A. M. (2010). The social and labor issues: State relations, new challenges and trends: Monograph. K. Kyiv, Ukraine: Kyiv National Economic University.

Kupets, O. (2012). Characteristics and determinants of internal labor mobility in Ukraine. Report No. 68824-ECA. Washington DC, WA: World Bank.

Retrieved from: https://openknowledge.worldbank.org/handle/10986/26804

Kupets, O., Vakhitov, V., \& Babenko, S. (2013). Ukraine case study: Jobs and demographic change. The World Development Report 2013. Washington DC, WA: World Bank. Retrieved from: https://mtu.gov.ua/files/for investors/Jobs\%20And\%20Demographic\%20Change\%20Ukraine\%202013.pdf

Markina, I., Sharkova, A., \& Barna, M. (2018). Entrepreneurship in the shadow economy: The case study of Russia and Ukraine. International Journal of Entrepreneurship, 22(3), 1-13.

Retrieved from: https://www.abacademies.org/articles/entrepreneurship-in-the-shadow-economy-the-casestudy-of-russia-and-ukraine-7457.html

Ministry of Social Policy of Ukraine. (2020). Internally displaced persons. Kyiv, Ukraine: Ministry of Social Policy of Ukraine. Retrieved from: https://www.msp.gov.ua/en/

Mishchuk, H., \& Grishnova, O. (2015). Empirical study of the comfort of living and working environment - Ukraine and Europe: Comparative assessment. Journal of International Studies, 8(1), 67-80.

DOI: https://doi.org/10.14254/2071-8330.2015/8-1/6 
Organisation for Economic Co-operation and Development. (2012). Ukraine sector competitiveness strategy. Competitiveness and private sector development. Paris, France: OECD.

Retrieved from: https://www.oecd.org/countries/ukraine/ukrainesectorcompetitivenessstrategy.htm

Petrova, I., \& Mosiychuk, T. (2016). Globalization impact on problems of innovation and economic security of Ukraine. European Journal of Economics and Management, 2(1), 130-135.

Retrieved from: https://eujem.cz/wp-content/uploads/2016/eujem 201621/23.pdf

Ptoukha Institute for Demography and Social Studies of the National Academy of Sciences of Ukraine. (2020). Retrieved from: https://www.idss.org.ua/index en

Refugees and Internally Displaced Persons. (2015). Retrieved from: https://www.ipu.org/about-ipu/structureand-governance/governing-council/committee-promote-respect-international-humanitarian-law/refugeesand-internally-displaced

Research \& Branding Group. (2020). Retrieved from: http://rb.com.ua/en/

Scheve, K. F., \& Slaughter, M. J. (2001). Labor-market competition and individual preferences over immigration policy. Review of Economics and Statistics, 83(1), 133-145. DOI: https://doi.org/10.1162/003465301750160108

State Statistics Service of Ukraine. (2020). Population and migration. Kyiv, Ukraine: State Statistics Service of Ukraine. Retrieved from: http://www.ukrstat.gov.ua/

Contact Ukraine. (August 16, 2016). Ukraine labor market updates 2016. (Message in a blog). Retrieved from: https://www.contactukraine.com/blog/ukraine-labor-market-updates-2016

Ukrainian Centre for Economic and Political Studies Named after Olexander Razumkov. (2019). The war in Donbas: Realities and prospects for settlement. National Security and Defence, 1-2(177-178).

Retrieved from: http://razumkov.org.ua/uploads/journal/ukr/NSD177-178 2019 ukr.pdf

United Nations Development Programme in Ukraine. (2010). Poverty and social impact analysis of the economic crisis in Ukraine. Kyiv, Ukraine: UNDP Ukraine.

Retrieved from: http://content-ext.undp.org/aplaws publications/2819389/1958-UNDP-PSIA-Report-LR.pdf

United Nations Development Programme. (2014). Human development report 2014. Sustaining human progress: Reducing vulnerabilities and building resilience. New York, NY: UNDP Ukraine.

Retrieved from: http://hdr.undp.org/sites/default/files/hdr14-report-en-1.pdf

World Bank. (2018). Moving for prosperity: Global migration and labor markets. Policy Research Report. Washington DC, WA: World Bank. DOI: https://doi.org/10.1596/978-1-4648-1281-1

World Data Atlas. (2020). Topics. Retrieved from: https://knoema.com/atlas/topics/

Zakharova, 0. (2019). Specificity of knowledge management in the enterprise in dependence on the stage of the person's life cycle. Journal of the Knowledge Economy, 10, 1447-1465. DOI: https://doi.org/10.1007/s13132-018-0550-0

Zakharova, 0., \& Kratt, O. (2014). Economic study and risk estime of the investment in the human capital. Economics \& Sociology, 7(2), 94-108. DOI: https://doi.org/10.14254/2071-789X.2014/7-2/8 